\title{
Study Search and the Perception of the Stakeholders of the Alumni Fakultaas Tarbiyah dan Ilmu Keguruan IAIN Padangsidimpuan
}

\author{
Suparni $^{1 *}$ \\ Fakultaas Tarbiyah dan Ilmu Keguruan IAIN Padangsidimpuan \\ *Corresponding author \\ Email:siparbejo33@gmail.com
}

\begin{abstract}
One measure of the success of a program organizers education is how the program graduates can be engaged or absorbed by the jobs that are available outside the campus, received an award from the labor market and that is much better is a graduate of the can to create new jobs so that it can absorb the graduates of the other that have not worked. The quality of an educational program can also be seen from the level of satisfaction of the users (Stakeholders). The reality on the ground is the magnitude of the number of graduates is not comparable with the field work that has been available. Also the alumni of the less ably meet the demands of field of working and operation are available, or entrepreneurship. There is also a sense of disappointment of the graduate users (stakeholders) of the competence of most of the alumni. This study aims to determine the absorption field work, knowing the perception of the stakeholders of the competence of the alumni and to determine the competencies or skills that should be given to the candidates for alumni of the Faculty of Tarbiyah dan Ilmu keguruan IAIN Padangsidimpuan that can answer the needs of the field work.the results of this study show that most of the alumni have worked on a variety of sectors, however, a large part can still work in the sector in accordance with their educational background that is from the field of islamic studies or education. Most stakeholders say positive things of the competence of the alumni FTIK IAIN Psp. Competency or skills that need to be given to the candidates alumni in accordance with the needs of the field work at this time is a skill in operating a computer, not just could be but smoothly and proficiently, especially in terms of data processing, such as MS Excel, Ms-Word, Power Point and technique organizes learning online that is effective and efficient.
\end{abstract}

Keywords: Perception of the Stakeholders, Alumni

\section{INTRODUCTION}

The process of education is conducted in order to improve the quality of human resources. College is one of the institutions that organize the process of education aims to develop the knowledge, expertise/skills and also attitude. These three things are the basic very important to be developed in order to answer the challenges of the world of work in the field.

The quality of the education can also be seen from the level of satisfaction felt by all Stakeholders. It is necessary to do an activity in order to obtain precise and accurate information related to any of the above issues as an attempt to improve the quality of graduates and accountability of institutions. Activities referred to in the form of "Tracer"or the study of search alumni. To be able to measure the extent to which the Faculty managed to form graduates that can be useful for the community need to be held Tracer Study aimed to stakeholders i.e., graduate or alumni and corporate users graduates/ alumni each year (Curup, 2018). The results of the tracer study will provide benefits directly to the Faculty because in addition to being monitoring, tracer study can serve as a feedback for the Faculty to evaluate and improve the curriculum, so that graduates can accommodate the needs of/public guidance. In addition, the results of the tracer study conducted also very beneficial for the Faculty as a support in accreditation. 
Based on the formulation of the problem which has been described in the above description, further research aims, among others:

1. To determine the extent of absorption of the field work of the alumni Fak.Tarbiyah dan Ilmu Keguruan IAIN Padangsidimpuan

2. To know the perception of the stakeholders of the competence of the alumni Fak. Tarbiyah dan Ilmu Keguruan IAIN Padangsidimpuan

3. To determine the competencies or skills that should be given to the candidates for the alumni in order to answer the needs of the field work.

\section{RESEARCH METHODS}

This research is a descriptive research, where the research is descriptive research that attempt to describe and interpret an object in accordance with what the, this research is also often called non-experimental research, because in this study the researcher does not control and manipulation of the variables of the study. furthermore, the population in this research is the alumni of the Faculty of Tarbiyah Science and Teacher training, precisely the class of 2015 to 2019.

Methods of data Collection that is looking for a data alumni of the Faculty of Tarbiyah Science and Teacher training by searching documentation file in a part of the general problem of the alumni class of 2015 - 2019 good it documentation in the form of a list of alumni, thesis or other files. Type of instrument of data collection this research is as follows:

1. Documentation

2. Questionnaire

The questionnaire used in the they were while this is kind of a closed questionnaire. Data management techniques in this research is using descriptive statistics. Where descriptive statistics are statistics that describe the activities of specialized data collection, preparation of data and data presentation in the form of tables, charts, or diagrams, so the members an overview of the regular, concise, and clear regarding a situation or event.

\section{RESULTS AND DISCUSSION}

Described data that has been collected during the implementation of the data collection in the field. Some of the information will be described as the result of the research, among others: the percentage of the gender of the alumni; the level of Education, the waiting time of work, type of work, the conformity between the work with the program of study, the suitability of competency with skills work, the suitability of the learning method which is given in the campus, the relevance of the learning experience outside the campus with the needs of the work, the suitability of the learning practices of worship taught in the campus with prakatek of worship in the community, the amount of salary earned per month, continuing the studidan source the cost of further studies.

1. Gender

\begin{tabular}{ccc}
\hline & GENDER & \\
\hline GENDER & MALE & WOMEN \\
PERCENTAGE & 32,1 & 67,9 \\
TOTAL & 44 & 93 \\
\hline
\end{tabular}


Volume 1, Number. 2, October 2021, Page. 29 - 34

Email : editorijhess@gmail.com

2. Studies Program Alumni

\begin{tabular}{lccccc}
\hline \multicolumn{7}{c}{ PROGRAM OF STUDY } & & \\
\hline & PAI & TBI & TMM & PBA & PGMI \\
PERCENTAGE & 23,4 & 19,7 & 49,6 & 4,4 & 2,9 \\
TOTAL & 32 & 27 & 68 & 6 & 4 \\
\hline
\end{tabular}

3. Education

\begin{tabular}{ccc}
\hline & EDUCATION & \\
\hline PERCENTAGE & S-1 & S-2 \\
\hline TOTAL & 85,4 & 14,6 \\
\hline
\end{tabular}

4. The waiting time of the first working

\begin{tabular}{cccccc}
\hline \multicolumn{5}{c}{ THE WAITING TIME WORK } \\
\hline & Less than 3 month & $3-6$ & $6-9$ & $9-12$ & More Than 12 \\
PERCENTAGE & 63,5 & 22,6 & 8,8 & 2,9 & Month \\
TOTAL & 87 & 31 & 12 & 4 & 7,1 \\
\hline
\end{tabular}

5. Type Of Work

\begin{tabular}{|c|c|c|c|c|c|c|}
\hline & & & WORK & & & \\
\hline & $\begin{array}{l}\text { Teacher/ } \\
\text { Lecturer } \\
\text { PNS }\end{array}$ & $\begin{array}{l}\text { Teacher/ } \\
\text { Lecturer } \\
\text { Private }\end{array}$ & $\begin{array}{l}\text { Employees } \\
\text { Private }\end{array}$ & $\begin{array}{l}\text { PNS } \\
\text { Non } \\
\text { Teacher }\end{array}$ & Entrepreneur & OTHER \\
\hline PERCENTAGE & 12,4 & 59,9 & 14,6 & 2,2 & 1,5 & 12,4 \\
\hline TOTAL & 17 & 82 & 20 & 3 & 2 & 17 \\
\hline
\end{tabular}

6. The suitability of the Type of Work with the Program of Study

\begin{tabular}{ccccc}
\hline \multicolumn{5}{c}{ THE CONFORMITY OF THE WORK WITH THE PROGRAM OF STUDY } \\
\hline & Very appropriate & Appropriate & $\begin{array}{c}\text { Quite } \\
\text { Appropriate }\end{array}$ & $\begin{array}{c}\text { Not } \\
\text { Appropriate }\end{array}$ \\
PERCENTAGE & 53,3 & 24,8 & 13,1 & 10,9 \\
TOTAL & 73 & 34 & 18 & 15 \\
\hline
\end{tabular}

7. The suitability of competency with Skills Work

THE SUITABILITY OF COMPETENCY WITH SKILLS WORK

\begin{tabular}{cccccc}
\hline & $\begin{array}{c}\text { Very } \\
\text { appropriat }\end{array}$ & Appropriate & $\begin{array}{c}\text { Quite } \\
\text { Appropriate }\end{array}$ & $\begin{array}{c}\text { Less } \\
\text { Appropriate }\end{array}$ & $\begin{array}{c}\text { Not } \\
\text { Appropriate }\end{array}$ \\
PERCENTAGE & 36,5 & 50,4 & 10,2 & 2,2 & 2,9 \\
TOTAL & 50 & 69 & 14 & 3 & 4 \\
\hline
\end{tabular}


Volume 1, Number. 2, October 2021, Page. 29 - 34

Email : editorijhess@gmail.com

8. The suitability of the method of learning that is provided in the campus

\begin{tabular}{cccccc}
\hline \multicolumn{5}{c}{ THE SUITABILITY OF THE LEARNING METHODS THAT ARE TAUGHT ON CAMPUS } \\
\hline & $\begin{array}{c}\text { Very } \\
\text { appropriate }\end{array}$ & Appropriate & $\begin{array}{c}\text { Quite } \\
\text { appropriate }\end{array}$ & Less appropriate & $\begin{array}{c}\text { Not } \\
\text { appropriate }\end{array}$ \\
\hline PERCENTAGE & 32,1 & 51,1 & 10,9 & 5,1 & 2,9 \\
TOTAL & 44 & 70 & 15 & 7 & 4 \\
\hline
\end{tabular}

9. The relevance of the Learning experience outside the Campus with the world of Work. THE RELEVANCE OF THE LEARNING EXPERIENCE OUTSIDE THE CAMPUS

\begin{tabular}{cccccc}
\hline & Very relevant & Relevant & $\begin{array}{c}\text { Quite } \\
\text { Relevant }\end{array}$ & Less relevant & Not Relevant \\
PERCENTAGE & 35,8 & 53,3 & 9,5 & 2,2 & 1,5 \\
TOTAL & 49 & 73 & 13 & 3 & 2 \\
\hline
\end{tabular}

10. The suitability of the Learning Lab Worship learned in college with Practice in the community.

\begin{tabular}{cccccc}
\hline \multicolumn{6}{c}{ THE SUITABILITY OF THE LEARNING LAB WORSHIP } \\
\hline \\
$\begin{array}{c}\text { Very } \\
\text { Relevant }\end{array}$ & Relevant & $\begin{array}{c}\text { Quite } \\
\text { Relevant }\end{array}$ & Less Relevant & Not Relevant \\
PERCENTAGE & 43,8 & 52,6 & 4,4 & 0,7 & 0,7 \\
TOTAL & 60 & 72 & 6 & 1 & 1 \\
\hline
\end{tabular}

11. The amount of Salary per month received

\begin{tabular}{cccccc}
\hline \multicolumn{7}{c}{ INCOME PER MONTH } \\
\hline PERCENTAGE & Less than 1 jt & $1-2$ jt & $2-4$ jt & $4-6$ jt & More than 6 jt \\
TOTAL & 30,7 & 34,3 & 30,7 & 4,4 & 2,2 \\
\hline
\end{tabular}

12. Further studies

\begin{tabular}{ccc|}
\hline & FURTHER STUDIES & \\
\hline & YA & TIDAK \\
\hline PERCENTAGE & 9,5 & 92,7 \\
TOTAL & 13 & 127 \\
\hline
\end{tabular}

13. The source of the cost of further studies

\begin{tabular}{cccc}
\hline \multicolumn{4}{c}{ THE SOURCE } \\
\hline & OF THE COST & OF FURTHER STUDIES \\
\hline PERCENTAGE & 8,0 & Self & Other \\
TOTAL & 2 & 32,0 & 60,0 \\
\hline
\end{tabular}




\section{CONCLUSION}

1. Related absorption field work against the alumni Fak. Tarbiyah dan Ilmu Keguruan IAIN Padangsidimpuan, it can be concluded that most of the alumni have been working working on various sectors, however, a large part can still work in the sector in accordance with their educational background that is from the field of islamic studies or education. Most of them are working as a lecturer/teacher, salaupun in private (almost 60\%). However, there are also as lecturers/teachers who are CIVIL servants (12,5\%).

2. Associated with the perception of the stakeholders of the competence of the alumni Fak. Tarbiyah dan Ilmu Keguruan IAIN Padangsidimpuan, most stakeholders say things that are positive. Alumni FTIK IAIN Psp generally obedient, Millennial, easy to cooperation and can adapt with the changing times, More able to understand the students ' character, Able to menyesuaikandiri with the community with a religious approach, able to compete in general with the alumni of other Universities, coupled with the alumni equipped with the science of religion, but it is also not far behind in terms of following the development of information technology.

3. Related to competence or skills that need to be given to the candidates alumni Fak. Tarbiyah dan Ilmu Keguruan IAIN Padangsidimpuan in accordance with the needs of the field work at this time, seabagian large stakeholders wanted the alumni who have skills in operating a computer, not just could be but lancer and proficiently, especially in terms of data processing, such as MS Excel, Ms-Word, Power Point and of course the needs of the times and the needs of the Education world today is a Technique of organizing learning online effectively and efficiently. In addition tenutunya competence is mandatory for a teacher to be owned, yaitu kompetensi paedagogik, personal competence, professional competence and the competence of the social.

\section{REFERENCES}

Curup, I. (2018). TRACER STUDY ALUMNI INSTITUT AGAMA ISLAM NEGERI.

Fajaryati, N., Pambudi, S., Priyanto, P., Sukardiyono, T., Utami, A. D. W., \& Destiana, B. (2015). Studi Penelusuran (Tracer Study) Terhadap Alumni Program Studi Pendidikan Teknik Informatika Jurusan Pendidikan Teknik Elektronika Fakultas Teknik Universitas Negeri Yogyakarta. Elinvo (Electronics, Informatics, and Vocational Education), 1(1), 4445. https://doi.org/10.21831/elinvo.v1i1.10878

Outcomes, L., \& Inti, K. (2012). Kerangka Kualifikasi Nasional Indonesia ( KKNI ). 1-5.

Rofaida, R., \& Gautama, B. P. (2019). Strategi Peningkatan Kompetensi Lulusan Perguruan Tinggi Melalui Studi Pelacakan Alumni (Tracer Study). Image : Jurnal Riset Manajemen, 8(1), 1-8. https://doi.org/10.17509/image.v7i1.23171

Schomburg, L., Schweizer, U., Holtmann, B., Flohé, L., Sendtner, M., \& Köhrle, J. (2003). Gene disruption discloses role of selenoprotein $\mathrm{P}$ in selenium delivery to target tissues. Biochemical Journal, 370(2), 397-402. https://doi.org/10.1042/BJ20021853 
Volume 1, Number. 2, October 2021, Page. 29 - 34

Email : editorijhess@gmail.com

Suryani, T., \& Basyir, M. (2020). Pengaruh kompensasi, kepuasan kerja dan budaya organisasi terhadap kinerja pegawai pada kantor sekretariat daerah kabupaten gayo lues $1 *$. Universitas Syiah Kuala, 1(1), 35-45.

Syaifullah, \& Soemantri, D. O. (2016). Pengukuran Kualitas Website Menggunakan Metode Webqual 4.0 (Studi Kasus: CV. Zamrud Multimedia Network). Jurnal Rekayasa Dan Manajemen Sistem Informasi, 2(1), 19-25. www.zamrudtv.com. 